\title{
Report of the work of jean-luc chodkiewicz (20l4): the aubrac in Paris: an investigation of Urban Ethnology
}

\begin{abstract}
The Aubrac in Paris is one of the first inquiries of urban ethnology realized in France in the middle of 1960s by Jean-Luc Chodkiewicz. It deals with internal migrations, exactly the way that aubracians farmers manage to integrate themselves into the Parisian context and the links which they maintained with their region of origin and to the influence of Paris on this region. This research occupies a marginal place in a research program centered on the economic and social transformations of a rural society and it, in a context where the French ethnology is lacking theoretical and methodological references to observe the urban phenomena. But from a historic approach, from multiple contacts extended with the migrants, a visit of Aubrac and from an important documentary corpus, the author succeeds in explaining the adaptation of Aubracians to the economic changes which affect their region and manners of which they manage to become integrated into an unfamiliar environment. In so doing, Chodkiewicz puts the bases of what will become the urban ethnology in France and the study of the observable migratory phenomena in city.
\end{abstract}

Keywords: Internal and international migrations, cultural preservation of the link, migrants' organization, integration of migrants, migrants' associations, connected migrants
Volume 2 Issue 2 - 2017

\section{Ebilitigué Ines}

Doctor in sociology, Université de Paris-Nanterre, France

Correspondence: Ebilitigué Ines, Doctor in sociology, Université de Paris-Nanterre, France, Tel 07838I5429, Email inesebilitigue@gmail.com

Received: October 23, 2017 | Published: November 20, 2017

\section{Introduction}

The Aubrac in Paris is an urban ethnology investigation realized by Jean-Luc Chodkiewicz (Lecturer at the University of Manitoba in Canada), published in 2014 in the publishing of the CTHS. This research joins in a Cooperative Research Program (RCP Aubrac) led between 1963 in 1966 and supervised by Georges Rivière (curator of the museum of the arts and the popular traditions) and André Leroi-Gourhan (ethnologist, archaeologist and French historian, specialist of the Prehistory). This report will try to present this book by specifying the context in which this research has begun, the way it is organized in the work, the difficulties which the author meets, his methodological choices and the contribution of his work to the current urban ethnology.

\section{Report and question of departure}

Researchers were interested in the observable mutations at the local level and particularly in the endangered agro-pastoral activity in Aubrac, French region situated on three departments: Aveyron, Cantal and Lozère. Their research is guided by the question to know how migrants coming from this region lived the passage from an economy based on a craft activity (the craft manufacture of the cheese) to an economy established on the production and the selling of the meat in Europe under construction The research program starts on the observations of an important internal migration of Aubracians farmers towards Paris, a Parisian influence on aspects of the Aubrac's region, the key role of regional fellowships created by these migrants for them and the possibility that those associations offer to observe the preservation and the evolution of some aspects of the aubracian culture. Then, the research is focused on the study of these regional fellowships to understand their design and their organization. The investigation is begun by Emmanuel Garig then, at the request of Georges Henri Rivière, confided to Jean-Luc Chodkiewicz

\section{Organization of the book}

The research is presented in five chapters. First ones, essentially descriptive, lead the reader in the history of Aubracians living in Paris since several generations. The main questions concern the way worked the migration, which were the relations between Aubracians stayed in Aubrac and those of Paris. Analyses are supported by demographic data informing trajectories of Aubracians, about their living conditions in Paris, the organization of families and profession which they occupied (at first specific, then more and more diversified). Through the plans of the demographic curves, the researcher seizes the peculiarity of the aubracian migration compared to other migrations coming from province towards Paris: a temporary nature in every generation. Other chapters are dedicated to the study of aubracians fellowships. The author tries to define these regional associations from their history, from their way of functioning and from the diverse functions which they fill in the time and in the space.

He notes that they represent a cultural intersection between Paris and the villages of Aubrac. These associations allow observing the links in the time and space between the migrants of Aubrac and their place of origin because of the important political, economic and social role which they play in it. Every aubrac's association in Paris relates to its village of origin and occupies an original and prominent place in its social order. The studying of those aubracians associations allows observing the relationships being able to within the Parisian community coming from the Aubrac and between this one and the political institutions of the localities of Aubrac. 


\section{Theorical and methodological approach}

In the research program, the research of Chodkiewicz occupies a marginal place because he was the only ethnologist of the urban among specialists of the rural world whom are the musicologists, ethnochoréologues and the ethnologists, etc. But this place was also marginal because theoretical and methodological references that dominate in the whole of the research program centered on the transformations of the countryside observable on the local plan. Chodkiewicz was centered on the world of the urban. He did not arrange theoretical and methodological references in ethnology which can serve him of support to study the adaptation of farmers in urban areas.

It is a point of difficulty for the author. However, his research indicates Martine Segalen, the preface writer of the work, is the one who in the program offers much information to understand the functioning of the aubracian society. His work joins in the lineage of Robert K Merton's works, ${ }^{1}$ an American sociologist. Thus, his search is a pioneer in France and contributes to put the bases of what will be the urban ethnology.

To manage its work, he mobilizes a diachronic approach by traveling the history of Aubracians to spot elements there allowing understanding what Aubracians is at the time of its study and their report in Paris and in Aubrac. This method allows him exactly to show that associations arose from relations built in the time which the Aubracians migrants maintained between them and with their earth of origin and that they represent the consecration of these relations. This methodological choice allows him to answer both the main objective of the research program (to encircle the adaptation of Aubracians to the changes which mark their pastoral economy) in which joins its investigation and to the one who concerns directly his search (Encircle the way former Aubracians peasant became integrated into an urban economic and social environment). His approach is also ethnographical by involving a visit of the Aubrac, long and regular time sharing with the investigated, proceed to interviews, participate in the events, is interested in the trajectories of Aubracians, in the life stories in Paris to identify the evolution of the economic and social status of his population sample, the consultation of the other researchers, the viewing of movies made by Jean-Dominique Lajoux and the consultation of archives.

\section{The state of urban ethnographic investigations}

At present, the French urban sociology and the anthropology count numerous works concerning the internal migrations and guided by questionings about those of the research of Chodkiewicz or about a part of the way he made the ethnology in town. The approached themes concern the economic and social adaptation of the families or groups of regional migrants in the economic and social evolution of the Parisian context since several generations. Bound to this theme represent authors as. ${ }^{2-4}$ These works offer a look on the evolution of descendants of aubracians in Paris.

But the questioning of Chaudkiewicz also finds itself in the works of the researchers centered on the international migrations.
Among them represent authors as Colette ${ }^{5-10}$ etc. Their analyses and methodological approaches are centered on migrant's areas in the city and allow identifying their economic and social adaptation to Paris and to regional cities as Marseille, Lyon, Le Havre, Mantes-la-Jolie. ${ }^{11}$ These works also show the evolution of the cultural links which the migrants maintain with their country of origin the more and more prominent place of ICTS in these relations.

Finally, the interest of the research for Chodkiewicz bases on its pioneer character and on the place which it offers to the study of urban phenomena in the French ethnology. This interest also bases on its approach, involving its questionings and its methodological approach to understand a migratory phenomenon in the work. This approach or a part inspires numerous sociologists and anthropologist of the urban whose works concern the theme of the migrants in town, of life cycle or life course. ${ }^{12}$

\section{Acknowledgements}

None.

\section{Conflict of interest}

Author declares there is no conflict of interest.

\section{References}

1. Robert M. Éléments de théorie et de méthode sociologique. Plon. France; 1953.

2. Marc A. Rouergats de Paris. Pour une anthropologie au present. Ethnologie Française. 1980;10(2):163-168

3. Marc T. Le Bougnat. Monaco. Editions du Rocher, 2000. p. 216.

4. Anne S, Sylvaine C. Portrait d'un bistrot des faubourgs: Le Mistral. Ethnologie Française. 2012;42(3):4471-4481.

5. Colette P. On est tous dans le brouillard. Ethnologie des banlieues. Editions Galilée, France; 1979. p. 544.

6. Emmanuel M, Michelle G. Les commerçants étrangers dans l'agglomération parisienne. Revue Européenne des Migrations Internationales. 1986;2(3):105-134.

7. Véronique R. Notes à propos de l'évolution de recherches françaises sur "létranger dans la ville". In: Barouh S, Pierre J, editors. Les étrangers dans la ville, le regard des sciences sociales. L'Harmattan, France; 1990. p. $60-80$.

8. Sophie BL. Femmes camerounaises en région parisienne. Trajectoires migratoires et réseaux d'approvisionnement, L'Harmattan, France; 1999. p. 242.

9. Anne R. L'Ethnique est quotidien, Diasporas, marchés et cultures métropolitaines. L'Harmattan. France; 2000. p. 229.

10. Anne R. Anthropologie urbaine. 2nd ed. Armand Colin, France; 2007.

11. Ines E. Réseaux virtuels et commerces ethniques: une dynamique entre l'espace des flux et l'espace urbain. Thèse de doctorat en sociologie, Université de Paris-Ouest Nanterre la Défense, France; 2014. p. 399.

12. Les Auvergnats de Paris. Editions du Rocher, 2001. p. 177. 